\title{
Application of Moral Investment of Enterprise in Constructing Harmonious Society
}

\author{
Sha Yanfei \\ College of Economics and Management,Huaiyin Institute of Technology,Huaian,China,223001;School of Business,Nanjing Normal \\ University, Nanjing,China. \\ Email: shamst@163.com
}

Received 2013

\begin{abstract}
The enterprise is the mainbody of the construction of harmonious society. The pivot to construct the harmonious society is to increase the moral investment.The moral investment should be operational and it can be done in three steps. The first step is to form the moral view. The second step is to make the decision on morality. The last step is to grip the moral carrier.
\end{abstract}

Keywords: Enterprise; Moral Investment; Moral Carrier; Harmonious Society

\section{Introduction}

In the context of ethics, the best comment to harmonious is "moderation". The so-called moderation, that is, don't go to extremes. Harmony has the outstanding quality, emboding the coordinating ability of the inner relationship around main body. Constructing the harmonious society can't just rely on external environment and power, more needs to be a inner of excellent quality as ethical basis. Enterprise is the people's assembly and is the carrier of exchanging relationship of material and spirit in enterprise inside and outside.Enterprise should intensify moral devotion, forging excellent quality to become a harmonious enterprise.

\section{The Sollen Requirements of Harmonious Society to the Enterprises}

Building a harmonious society is an important task to the present and future of China, it relates to the productive forces and production relations, the economic base and superstructure, economy and ethics, enterprise and society and other major social relations. There is no shirking the responsibility for the enterprise to building a harmonious society

First, enterprises should become the basic material carriers of building a harmonious society. Economy is the basis, while economic growth and social development is the only key to coordinate the interests of all parties, to reduce tension, to narrow the gap between urban and rural, to balance development among regions, and it's the important content of building a harmonious soci- ety. If without the strong support of the material wealth of the enterprise, the construction of harmonious society can only be an ideal.

Second, enterprises should become the basic material carriers in harmony with human and nature. Enterprises produc products and services through the integration of resources, creating wealth for society. At the same time, enterprises are constantly transporting all kinds of waste to the environment which directly affects people's quality of life. What is most concern that the large number of local and enterprises have not yet established the scientific concept of development, only pursuing the mere GDP growth while ignoring the endurance of environment and resources .

Third, enterprises should be the stabilizer to maintain the social stability. That whether a company provides adequate employment position to minimize the unemployment rate is an important part of maintaining social stability. Enterprise is the most important places of employment of social labor, the fundamental channel to solve the social employment problem. Enterprises provide the community with a large number of jobs, thus effectively safeguarding social stability. Imbalance in the distribution of material wealth easily leads to the gap between rich and poor, resulting in a tense labor relations between cadres and masses, while enterprise is the first part of the social distribution. The first allocation size of the enterprises and the structure reasonable or not is related to the stability of enterprises. The historical facts show that the instability of the enterprise often leads to major social problems. 
Fourth, enterprises should be space-time vector of the people to live in harmony. Enterprises, especially SMEs absorb a lot of the labor force, the enterprises' economic efficiency and the mode of distribution of profits directly affects the income and living standards of employees, thereby affecting the large and small families behind. Enterprises, as the space of the material and production activities, provides the working environment, working places, working conditions, working atmosphere and culture atmosphere for the employees which affect the physical and mental health of employees; A long period of time of staffs is spent in the enterprises. Enterprises should practice the scientific concept of development to achieve sustainable development and to provide material and spiritual conditions for the employee.

Finally, ethical investment should be the starting point of building a harmonious enterprise.Ethical investment of enterprise is that an enterprise through the formation of moral values, moral decision-making, grasping the moral carrier and other forms achieve value-added of moral elements. The harmony of the enterprise can be divided into two parts: the internal harmony and external business harmony. The core is to correctly handle the relationship between enterprises and stakeholders, taking the obligation of enterprise citizenship. Moral value as a tool can become an important means of harmoniously dealing with the relationship between internal and external enterprise, as inputs to the building of a harmonious enterprise. Wang Xiaoxi (2002) considered morality as the capital areas, was a force and a ability that can be put into production so as to enhance the wealth of society capacity. Compared with the construction of business ethics and enterprise social responsibility, moral investment of enterprise more emphasizes the micro-level operability and feasibility.

\section{The Possibility Analysis of Moral Investment of Enterprise}

Today, the business environment is increasingly complex. The managers have to cope with external uncertainty in the relatively complex way. Harmoniously managing the enterprises and increasing moral investment become a rational choice for enterprises. First, ethical supply has become the consensus of the community, and society is calling for a moral revival. Ethical investment depends on the support of social environment. Ethical investment will become possible only society approves, accepts and demands moral. China's economic and society have developed to a certain level and have get the support of other social norms (laws, political system). The community generally calls for morality. The basic elements of morality are mankind's common moral beliefs, such as love, honesty, fairness, tolerance and so on. No countries, nations, businesses and persons can exist without moral- ity.

Second, a general increase in the quality of the staffs makes ethical investment which have internal basis. The point of ethical investment is to improve people's moral qualities, to improve the old mode of possession. Whether it is through social education, family education, or even enterprise education, the quality of the employees generally improves, and they are more clear and initiative to the understanding and need of morality and they have the ability of moral awareness and moral behavior. Therefore, enterprises can subjectively change the ethical spirit throughout the economic activity and economic behavior to an ethical habits and a moral ideal. "Good" business leaders is not just men or women good at the management techniques, but also a model with moral integrity and professional expertise.

Third, the moral investment is in response to long-term needs of the business interests. Based on the pursuit of the interests of long-term, Business can be able to find more effective means of economic management. Xu Dajian (2002) considered the economic management with high efficiency was simply attributed to two aspects: resources allocation of the matter and incentive constraints of people. We know that the role of people is behind resources allocation of the matter. High efficiency, long-lasting incentives is no doubt the ethics and morality. Unified and noble ethics will inspire the sacred feelings of its members, it can offer daily production and exchange activities with deeper meaning, and makes ordinary, mechanical, repetitive operation show color, so that the workers' cooperation, loyalty and creativity are excited, and economic life has the nature of a moral life.

Finally, ethical investment and investment of other elements enhance the value of the element. Ethical investment and other elements investment( or known as physical capital) has a symbiotic, depending on with physical capital. The ethical investment born with the physical capital investment and play its own unique features. It converts into physical capital or promots physical capital to add value to get the meaning of their own existence and social recognition. While the operation of the physical capital also need the penetration and function of ethical investment from the inherent nature, it will achieve the largest and most optimized value-added of their own value because of the ethical investment. Therefore, the most obvious manifestation of ethical investment is the value-added of physical capital and so that it get the moral investment in both spiritual and material aspects of the dual value, which particularly reflected in human capital.

\section{The Form of Achievement to Moral Investment}

Morality, as elements, is different from labor, capital, 
land, entrepreneurs ability and other production factors in the form and content. It's difficult to be accounted for as a dominant cost. But staff training and education, enterprise mission and strategy, management decision-making are covered by ethical, and moral will infiltrate these areas. Combined with the enterprise strategy, The form of achievement to the ethical investment has three specific ways.

\subsection{To Form Justice and Benefit Symbiotic Business Ethics}

Different morality determines different directions, different dynamics and different means of enterprises development. Obviously, an unscrupulous business is not sensitive in ethics, and the sensitivity of the different business is not the same. This is related to both the enterprise itself in the socio-economic status and their own moral heritage. Under the conditions of market economy, market competition plays an important role on the morality. It promotes the intercom morality with the relatively complete punishment mechanism in social motivation and also has inhibitory effects on the formation of moral values in social punishment. OU Yang Run-Ping (2003) believed that enterprises could form three kinds of ethics: justice and benefit co-exist, righteousness and compatibility. Commensalism meant that under normal circumstances, the justice would not damage the interest or interest would not damage justice, which was the so-called justice and benefit co-exist, as far as possible justice and president were the same; In exceptional circumstances, it was prevail to save the survival of the enterprise profits. The enterprise of justice and benefit, or as "social response" business, neither be the wicked, nor be the moral leader, not profiteering, or pays the cost of more moral. The so-called justice and benefit compatibility means that profit must first seek justice, and the raising of the righteous makes a profit. The enterprise is a product of society, the enterprise's value is to create value for customers, and the development of enterprises relies on the support of stakeholders, so enterprises must first keep justice, and then get the benefit. The so-called coexistence of justice and benefit means justice is at the head, and then the interest. Enterprises inside focus on staff to promote the comprehensive development of the staff. External stakeholders shared interests, continue to create value for customers, in harmony with nature, and pursue sustainable development. Obviously, Righteousness and Symbiosis is the highest state of enterprise ethics, Panasonic, Haier Group, the world-famous enterprises are the practice of morality, not only won the praise of the world, also received a huge economic benefits.

\subsection{Making Moral Decision}

Making moral decision first must fulfill their moral re- sponsibility according to the enterprises and select the appropriate climbable moral goals. The enterprise is a target entity, having both economic goals and moral objectives. Economic target itself is flawed, often paying more attention to objects than to men, even though the emphasizing on man, also paying more attention to the material needs and economic interests, while ignoring the people's spiritual needs and moral interests. The goal of business's ethics is about people and society in general welfare of value orientation. Goal of the enterprises' ethics is stressed that any act of the enterprise has moral values, not just economic value. Compared with the enterprise economic goals, the fundamentally different is the relationship between altruism and self-serving and relationship between justice and profit. The moral goal is the fair value of the last line of defense, which requires that enterprise motivation is not purely self-serving, and should respect the legitimate interests of others as a prerequisite to obtain their own interests exist. Facts have proved that economic goals and moral goals are the premise and only talking about the goals of economic goals and morality enterprise is ultimately the most uneconomical; and only talking about moral goals not speaking the economic goals of the enterprise would ultimately damage the moral.

Taking the fact that the economic goals and moral objectives does not correspond to the state into account, when moral enterprises make decisions, they will first remove the unethical business decisions, and choose the best from several groups of economic decision-making. In this regard, it can refine moral goals to identify the most important moral goal to be met first. Xu Dajian (2002) believed that the principle not infringing the rights of others was better than the principle in favor of the rights of others, in other words, when some practices were conducive to the interests of many people while they would infringe the basic rights of some people, it should follow the principles of justice, fairness and abandons this approach. On the problem of not infringe the rights of others, the right to life and safety take precedence over other basic rights. Under certain historical conditions, the principle of economic efficiency takes precedence over the economic principle of fairness.

\subsection{Grasp the Moral Carrier}

Moral investment requires to infiltrate the moral among the other factors of production and also to be reflected in a series of material carriers.

\subsubsection{Grasp the Institutional Carrier}

Systematically, any kinds of organizations are a major obstacle of the ethical behavior, the enterprise organizational structure is formed an obstacle to moral behavior 
at least in three aspects: the division of labor, the dispersion of decision-making authority, level command system. Because of more and more professional and sophisticated division of labor, the employees can only undertake highly specialized local work, because they can only limited understand the results of their work, increasing the difficulties of coordination and communication, so they will lose an important prerequisite for being responsible for the behavior and reflecting on ethical. Therefore, the division system of the enterprise is limited, at least to be able to ensure that the enterprise have the necessary opportunities of communication and coordination, enabling the employees to have the responsibility space of self-discipline. To the enterprise level command, is frequently used in the system which to implement the strategic intent, but it will also bring serious ethical problems. Its effectively implementation, operation must be based on the decision-makers' wise, righteousness and reason, otherwise it will appear similarly to the terrible consequences of the Nazi regime. In this sense, the leadership's moral character relates to the enterprise's extinction. It is necessary that moral input would solve the problems of the enterprise's inherent hierarchy and command system replaced by democratic, scientific decision-makings.

The implementation of the internal institutionalization of enterprise ethics is important to grasp the moral carrier. The so-called Internal institutionalization of the enterprise ethics refers to, in the building of the internal organizational philosophy and behavior, except for those non-ethical behavior's motivation and incentives, import the correct moral judgment baseline, and as this a management system for standardizing the behavior of all employees. In the internal institutionalization of ethical management, the priority of the work of the American enterprises is to develop an enterprise moral behavior. Many enterprises assemble it into a booklet, to do many provisions on the project. Such as IBM's codes of conduct of the acceptance of gifts: if the value of accepted gifts are higher than non-ordinary relationships, or when sends money to the home or office, you must report to the superiors, then the higher will return the gift or other appropriate treatments. Setting Ethics Committee and ethical responsibilities in the enterprise, is also an important part of grasping the moral carrier. Moral responsibilitties persons is responsible for day-to-day moral management, prevention and control crisis incidents. The Ethics Committee is a special meeting which the enterprises regularly convened to deal with business ethics issues. When the enterprise is ready to enter new areas or make major decisions, the committee should make the following moral standards, researches the ethical issues in the report and improves the program. The committee majority consists of the operating personnel, absorbing the person in charge of personnel, marketing, finance, production and other departments to participate. Therefore, the Ethics Committee is the highest decision-making body of the enterprise moral management.

\subsubsection{Grasp the Product Carrier}

Although the product is a thing, any product all is spiritual thing. First of all, any product is designed which all according to the people's level of understanding about technological and cultural and technology path. It can be said, how many products there are that so many different cultural and technological materialized body. Secondly, any product is also all the materialization of the human's moral values or moral quality, and Han amount of products in the moral ultimately determines the quality of the product. Han amount of moral and ethical of the product is mainly composed of the elements of the product's humanization designing, production responsibility and the basic concept of production. The product's humanization designing requires that designers not only to pay attention to the physical needs of the people, that focus on the natural attributes and make products to meet the needs of the people's value in use of the product, but also to pay attention to people's spiritual needs, and make new products to meet the people's demands for the product value, including aesthetic values, moral values. The product designing is foundation, the production is the key. Good product designing is not equal to produce the products which meet the design requirements, and the high quality design is not meaning the high-quality products. The spirit of creating customer value should permeate all links and all aspects of the manufacture of products. Strictly, a desire of creating a brand and development enterprises should not appear a failed product in the production process, in the event that appears, the product should not be out of the factory door and not sell. Many well-known enterprises in China have an experience of destroying the unqualified products, one is to notice the social, the enterprise products are all qualified products; second is to educate their employees, that the qualified products are the employees responsibility and the crystallization of conscience.

\subsubsection{Grasp the Vividness Carrier}

The enterprise image is a holistic concept, including product image, brand image, price image, staff image, but each image contains the moral image, in other word, enterprise image eventually attributed to the moral image. Enterprises in general adopt the CI strategy to build enterprise image. CI strategy inputs new vitality for enterprise ethics. CI strategy is based on quality products, focusing on reputation, excellent service, pursuing understanding and trust of the public enterprises to establish a better enterprise image outside. This requires enter- 
prises to pay attention to social ethics, focusing on business ethics, and conscientiously fulfill their social responsibility, public-spirited undertakings and more strictly regulate the behavior of employees at the same time, and actively cultivate a good awareness of professional ethics for employees. This moral construction and ideological education under the overall control of the CI strategy that actively establishes the staff's image are clearly more to life than the traditional top-down simple moral preaching. It combines education and training of employees and normative constraints which is strong operational so that it can input it to inject new vitality for the moral.

\subsubsection{Grasp the Public Opinion Carrier}

The public opinion of enterprise can be divided into a formal opinion and informal public opinion. Publicity formal opinion can be created by the enterprise's internal publication, network and broadcast. The informal opinion is often helped by the conversation at rest of work. Business leaders should take full advantage of public opinion vector, so that they can understand the business moral situation and the mind of employees, and be better able to do staff moral education, using entrepreneurial spirit, the values to command staff and to form a strong cohesion. Employees use the carrier of the public opinion and continue to receive moral education, strengthening moral cultivation. Of course, all this must be established in the correct direction of public opinion on this end, therefore, the staff responsibility for moral opinion shoulder the important task of the moral guide. Their own moral sensitivity, moral consciousness, moral training degree is the basis of the exercise of the functions of public opinion.

\section{Conclusion}

Enterprise's three levels moral method makes more operable moral investment to construct a harmonious enterprise. Moral input of enterprise is different from the general inputs, but moral investment can bring more long-last benefits than other inputs, but also by moral devotion, other elements of the value of inputs can be guaranteed and are constantly amplification. Both the quantity and quality of moral investment are related to the enterprise's own strategic, and also can in turn affect enterprise development strategies. Through the moral investment, enterprise is not only harmonious to internal relations, also the external relations.

\section{REFERENCES}

[1] Wang XiaoXi. More on moral investment [J]. J ournal of jiangsu social science, 2002

[2] XuDaJian. Enterprise ethics [M]. Shanghai: Shanghai people's publishing house, 2002

[3] OuYang RunPing. Enterprise ethics [J]. Hunan people's publishing house, 2003

[4] Zucheng Zhou. Competitive advantage based on superior ethics [J]. Nankai Business Review, 2002 (2) :60-63

[5] Shuming Zhao. Elements of enterprise social responsibility, the latest model and strategy Review [J]. Foreign Economics and Management, 2009 (01) :2-8

[6] Jacob M. Rose. Enterprise Directors and Social Responsibility: Ethics versus Shareholder Value [J]. Journal of Business Ethics (2007) 73:319-331

[7] Desheng Sun. Top Management Team and Enterprise Social Responsibility: a perspective of high order [J]. Science and Technology Management, 2009 (04) :188-192

[8] Liangding Jia, Sanduo Zhou. Discuss on the entrepreneurial spirit and the Fve Discipline [J]. Nanjing Social Sciences, 2006 (09) :29-35

[9] Zhongwei Chen, Xiling Hao. Entrepreneurial team, entrepreneurial spirit and its measurement $[\mathrm{J}]$. Business Economics and Management, 2008 (09) :23-28

[10] JingJing Wang, Jieshan Yang. Study on Entrepreneurial Social Responsibility and Future Research [J]. Henan University of Technology (Social Sciences), 2010 (03) :35-39

[11] Yanfei Sha, Xiaobing Zhang. SME relationship between social responsibility and entrepreneurship research [J]. Continuing Education Research, 2010 (06) :167-169

[12] Peter. Drucker. Innovation and Entrepreneurship [M]. Machinery Industry Press, 2007 (01)

[13] Wenfang. Empirical Research on Enterprise life cycle impact of R \& D investment [J]. Economic Survey, 2009 (06) :86-898

[14] Qianming Huang. Discuss On the business model innovation and entrepreneurship - the analytical framework Based on Resource View[J]. Reforms and strategies, 2009 (08) :163-165 